\title{
Three species of Potyvirus genus recorded in ornamental plants, in Brazil
}

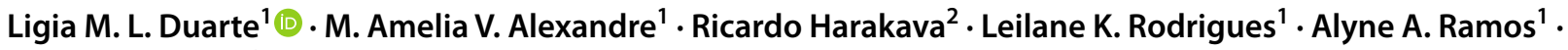 \\ Elliot W. Kitajima ${ }^{3}$
}

Received: 20 May 2021 / Accepted: 1 September 2021 / Published online: 25 September 2021

(c) Australasian Plant Pathology Society Inc. 2021

\begin{abstract}
Pepper yellow mosaic virus on Petunia hybrida, bean yellow mosaic virus on Viola odorata and Narcissus yellow stripe virus on Narcissus cyclamineus were identified in Brazil using RT-PCR. Serology, mechanical transmission, host range, and electron microscopy were used to study the viruses further.
\end{abstract}

Keywords Bean yellow mosaic virus · Narcissus yellow stripe virus · Pepper yellow mosaic virus

The ornamental plant market in Brazil is growing due to the introduction of novel flower colours and shapes of widely traded species, and the introduction of new species and varieties. Commercially exploited since the 1950 s, the sector has expanded in recent decades, mainly due to improved socioeconomic conditions, distribution of novel plants and the expansion of flower-growing areas (Paiva et al. 2020). Brazil has about 8,300 producers and 15,600 hectares of cultivated area, making it the world's 8th largest producer of ornamental plants (Portal do Governo 2019).

Viral diseases, however, may cause production losses, especially those from the genus Potyvirus (family Potyviridae, order Patatavirales), which induce leaf or floral symptoms. In addition to being transmitted by aphids in a nonpersistent manner, potyviruses may accumulate in plants such as ornamental flowers grown from bulbs or rhizomes (Revers and Garcia 2015; Wylie et al. 2019).

This paper reports the occurrence of three potyviruses with different characteristics in ornamental plants: (i) bean

Ligia M. L. Duarte

ligia.duarte@sp.gov.br

1 Laboratório de Fitovirologia Fisiopatológica, Instituto Biológico, Av. Cons. Rodrigues Alves, 1252, São Paulo, SP 04014-002, Brazil

2 Laboratório de Biologia Molecular Aplicada, Instituto Biológico, Av. Cons. Rodrigues Alves, 1252, São Paulo, SP 04014-002, Brazil

3 Escola Superior de Agricultura Luiz de Queiróz, USP, CP 09, Piracicaba, SP 13418-900, Brazil yellow mosaic virus (BYMV) of common occurrence, (ii) Narcissus yellow stripe virus (NYSV), restricted to a few hosts, and (iii) pepper yellow mosaic virus (PepYMV), a vegetable potyvirus possibly originating in central Brazil.

Samples of Narcissus cyclamineus (Amaryllidaceae) showing faint mosaic and stripes, Petunia hybrida (Solanaceae) with mosaic and Viola odorata (Violaceae) with mosaic and necrosis symptoms (Fig. 1) were collected from ornamental flower beds or purchased from a flower market in São Paulo state.

Leaves from the three naturally infected ornamental species were ground in $0.01 \mathrm{M}$ phosphate buffer, $\mathrm{pH} 7.0$, containing $0.5 \%$ sodium sulphite and the extracts were rubbed on carborundum-dusted leaves of Chenopodium giganteum, C. quinoa (Amaranthaceae) and Nicotiana glutinosa, $N$. megalosiphon and N. benthamiana (Solanaceae). Successful inoculation was determined by symptom expression and assayed by serological tests. The petunia virus induced systemic symptoms in N. megalosiphon. Viruses from the other infected species were not mechanically transmitted to the inoculated indicator hosts. Extracts from infected $P$. hybrida (petunia) and V. odorata (sweet violet) were inoculated into the original hosts and the symptoms reproduced. However, the original symptoms in $N$. cyclamineus (narcissus) could not be reproduced because healthy seedlings could not be obtained.

The presence of elongated flexible particles, ca. $700 \mathrm{~nm}$ long, were observed in negatively stained leaf extract of the three symptomatic species. Cylindrical inclusions characteristic of potyvirus infection in a palisade parenchyma cell 


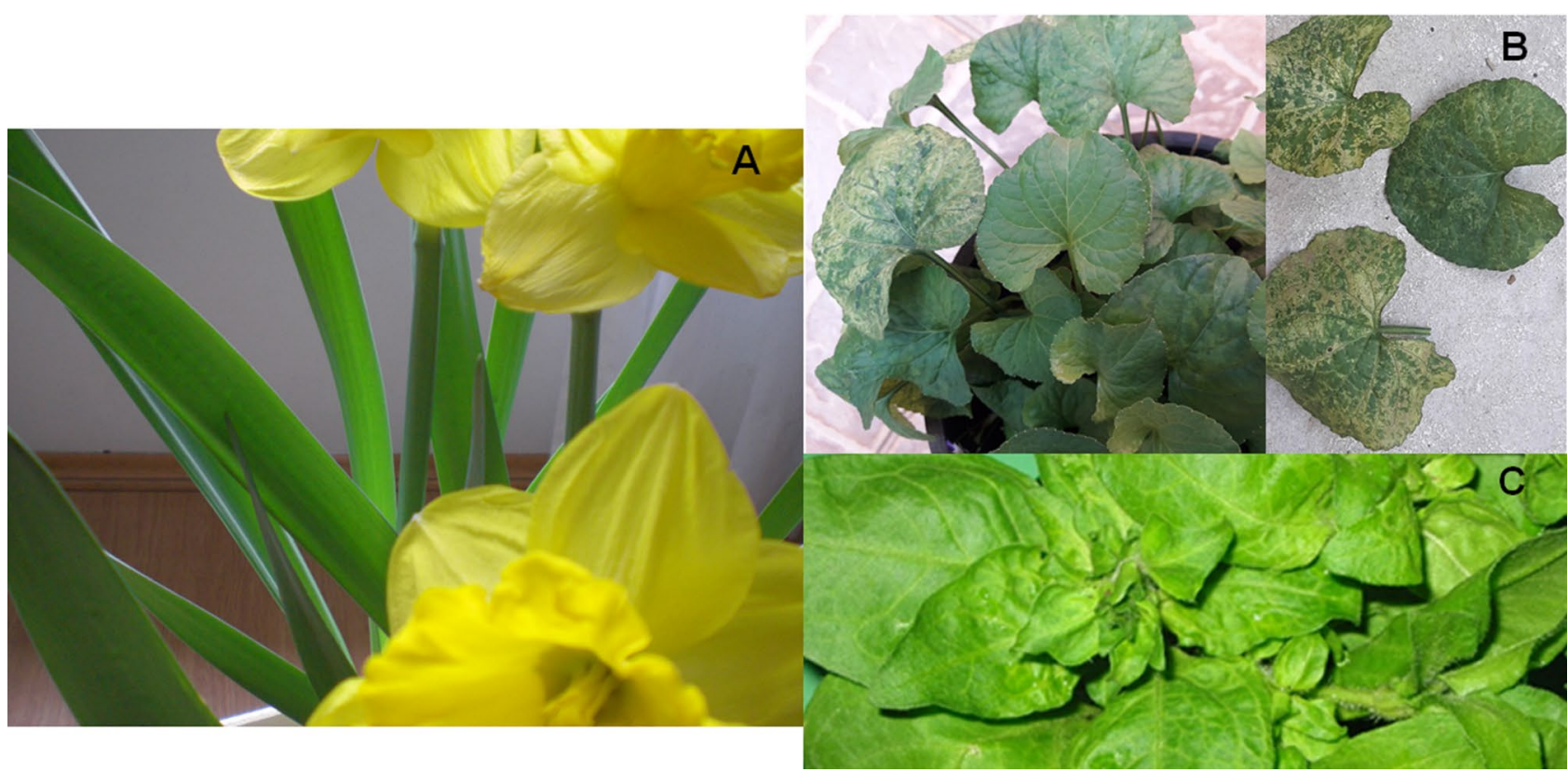

Fig. 1 Leaf symptoms exhibited in a naturally infected plants: A Narcissus cyclamineus with faint mosaic and stripes; B Viola odorata with mosaic and necrosis; C Petunia hybrida with mosaic

cytoplasm were observed in symptomatic $V$. odorata leaf extract (Fig. 2).

When leaf extracts from naturally infected samples were submitted to serological tests with potyvirus group antiserum (ACP-ELISA, AGDIA®) according to the manufacturer's instructions, only petunia yielded a positive reaction, with absorbance values $(\mathrm{A} 450=0.926)$ approximately 40 times higher than those of the healthy petunia plants (A405 $=0.022)$. Moura et al. (2011) also reported a positive reaction with the same antiserum. It is important to emphasize that although the Potyvirus group antiserum (ACP-ELISA, AGDIA®) reacts positively with BYMV and NYMV, as tested and reported (https://www.agdia. com/testing-services/potyvirus-group-test), the results were negative for Brazilian isolates of these viruses from $V$. odorata and $N$. cyclamineus. It is possible that these viral isolates exhibit antigenic specificity that differs somewhat from that of the other strains, as previously reported for BYMV (Granett and Provvidenti 1975).

Total RNA was extracted from symptomatic samples using TRIzol, following the manufacturer's instructions (Ambion life technologies, USA). RT-PCR amplified a 700 bp fragment corresponding to the potyvirus cytoplasmic inclusion (CI) region, using the same primers

Fig. 2 Transmission electron micrograph of the potyvirus associated with mosaic symptom of Viola odorata. A Negatively stained leaf extract of symptomatic $V$. odorata, showing an elongated flexible particle, ca. $700 \mathrm{~nm}$ long, suggestive of infection by potyvirus. B Thin section of symptomatic $V$. odorata leaf, showing laminated aggregates (LA), in a palisade parenchyma cell cytoplasm
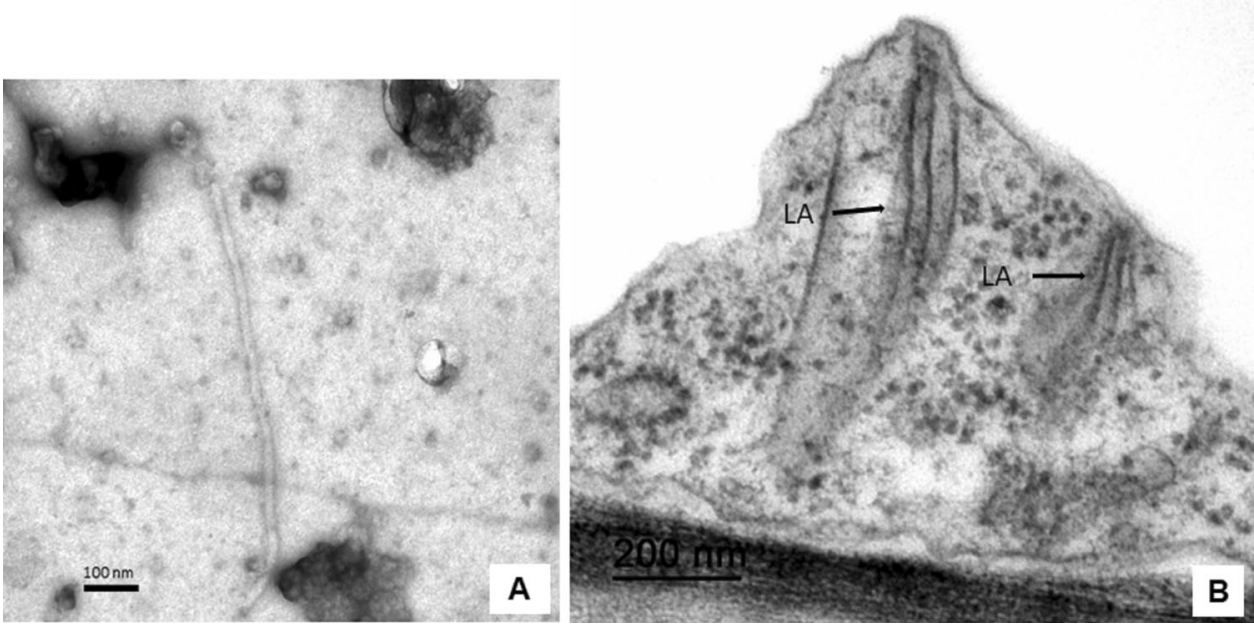
Table 1 Comparison between potyviruses from Petunia (PepYMV-Pet-19), Narcissus (NYSV-Nar-2) and Viola (BYMV_-Viola-SP) nucleotide and amino acid sequence identities and 22 other sequences of potyvirus

\begin{tabular}{|c|c|c|c|c|c|c|}
\hline & \multicolumn{2}{|c|}{$\begin{array}{l}\text { MN340313/PepYMV- } \\
\text { Pet-19 }\end{array}$} & \multicolumn{2}{|c|}{$\begin{array}{l}\text { MN365272/NYSV- } \\
\text { Nar-2 }\end{array}$} & \multicolumn{2}{|c|}{$\begin{array}{l}\text { MN365273/ } \\
\text { BYMV_Viola- } \\
\text { SP }\end{array}$} \\
\hline & nt & aa & $\mathrm{nt}$ & aa & $\mathrm{nt}$ & aa \\
\hline MN340313/ PepYMV—Pet-19 & - & - & 61.2 & 59.5 & 62.6 & 64.6 \\
\hline PepYMV/AB541985 & 93.4 & 97.7 & 61.0 & 60.6 & 61.2 & 63.5 \\
\hline HyMV/KU870775 & 63.9 & 67.5 & 63.3 & 63.5 & 65.4 & 69.1 \\
\hline PRSV/MN364666 & 60.1 & 64.0 & 59.5 & 59.0 & 61.2 & 61.8 \\
\hline CIYVV/KU922565 & 60.3 & 62.9 & 59.9 & 60.6 & 73.0 & 82.0 \\
\hline PTMV/AJ437280 & 72.1 & 80.9 & 61.5 & 59.0 & 62.5 & 64.6 \\
\hline BruMV/JX867236 & 72.5 & 81.5 & 61.0 & 60.1 & 62.5 & 61.2 \\
\hline PVY/MT380738 & 71.0 & 77.5 & 59.7 & 59.5 & 60.7 & 62.4 \\
\hline MN365272/ NYSV—Nar-2 & 61.2 & 59.5 & - & - & 62.9 & 61.2 \\
\hline NYSV/LC314397 & 62.0 & 60.7 & 89.3 & 90.4 & 62.4 & 61.8 \\
\hline NLSYV/MH886515 & 60.7 & 61.8 & 76.6 & 84.8 & 62.7 & 64.5 \\
\hline NV1/LC314399 & 64.0 & 62.9 & 73.2 & 83.1 & 65.4 & 63.5 \\
\hline TuMV/AP017737 & 63.5 & 68.0 & 67.6 & 69.1 & 63.3 & 66.8 \\
\hline WoSV/LC159495 & 60.5 & 62.4 & 68.5 & 74.2 & 62.5 & 62.4 \\
\hline MN365273/ BYMV_-Viola-SP & 62.5 & 64.6 & 62.9 & 61.2 & - & - \\
\hline BYMV/AB439730 & 62.5 & 64.6 & 61.6 & 61.2 & 97.6 & 99.4 \\
\hline HuPLV1/KX884567 & 62.7 & 65.7 & 63.3 & 62.4 & 80.9 & 96.6 \\
\hline WLMV/DQ641248 & 64.0 & 64.6 & 64.8 & 63.8 & 80.3 & 95.5 \\
\hline CIYVV/MN399731 & 59.9 & 62.4 & 59.9 & 61.8 & 76.0 & 80.3 \\
\hline OBPV/MN723596 & 60.3 & 62.9 & 60.5 & 60.7 & 73.2 & 82.0 \\
\hline HMV/MH779476 & 62.2 & 64.0 & 60.1 & 58.4 & 67.0 & 68.0 \\
\hline SPVG/MH388503 & 61.0 & 65.2 & 62.7 & 63.5 & 65.0 & 66.3 \\
\hline TBV/MH886517 & 61.4 & 65.7 & 62.5 & 64.0 & 66,8 & 71.3 \\
\hline CDV/JQ801448 & 65.2 & 66.8 & 61.8 & 57.9 & 66.5 & 65.2 \\
\hline SPFMV/MG656421 & 62.5 & 65.2 & 62.7 & 62.9 & 65.9 & 67.4 \\
\hline
\end{tabular}

BruMV Brugmansia mosaic virus, $B Y M V$ bean yellow mosaic virus, $C D V$ Colombian datura virus, $C l Y V V$ clover yellow vein virus, $H M V$ henbane mosaic virus, $H u P L V 1$ Hubei poty-like virus $1, H y M V$ Hyacinth mosaic virus, $N L S Y V$ Narcissus late season yellows virus, $N V 1$ Narcissus virus 1, NYSV Narcissus yellow stripe virus, $O B P V$ Ocimum basilicum potyvirus, $P e p Y M V$ pepper yellow mosaic virus, $P R S V$ papaya ringspot virus, $P T M V$ Peru tomato mosaic virus, $P V Y$ potato virus Y, SPFMV sweet potato feathery mottle virus, $S P V G$ sweet potato virus G, $T B V$ Tulip breaking virus, $T u M V$ turnip mosaic virus, $W L M V$ white lupin mosaic virus, WoSV wild onion symptomless virus

\section{(CI-F-GGIVVIGTIGGIWSIGGIAARTCIAC and CI-R-} ACICCRTTYTCDATDATRTTIGTIGC) and conditions recommended by $\mathrm{Ha}$ et al. (2008). The directly sequenced fragments in both forward and reverse directions using PCR primers in an ABI PRISM377 sequencer (Applied Biosystems) were deposited in the GenBank sequence database under the following accession numbers: P. hybrida (MN340313), N. cyclamineus (MN365272) and V. odorata (MN365273). The sequences used in the analyses were obtained after being submitted to the Basic Local Alignment Search Tool (Blast 2.0) (http://www.ncbi.nlm.nih. gov/BLAST/), and aligned with Potyvirus species using the CLUSTAL X program. The highest identity percentages in the nucleotide (nt) and amino acid (aa) of the different potyviruses isolated from $P$. hybrida, $N$. cyclamineus and $V$. odorata were obtained with PepYMV strain DF (AB541985), NYSV isol. NY-HG27 (LC314397) and BYMV strain G (AB439730), respectively (Table 1), which were designated PepYMV-Pet 19, NYSV—Nar 2 and BYMV-Viola-SP.

Phylogenetic analyses constructed by maximum likelihood (ML) PAUP v. 4.0b10 software revealed that PepYMV -Pet 19 shared the same common ancestor as the Brazilian isolate PepYMV. NYSV-Nar 2 and BYMV-Viola-SP formed a sister group with the NYSV Japanese isolate from $N$. tazzeta var. chinensis and the BYMV Japanese isolate from the Gladiolus hybrid (100\% bootstrap), respectively (Fig. 3).

Recently introduced in Brazilian floriculture, Narcissus plants have been well accepted in the market. However, 


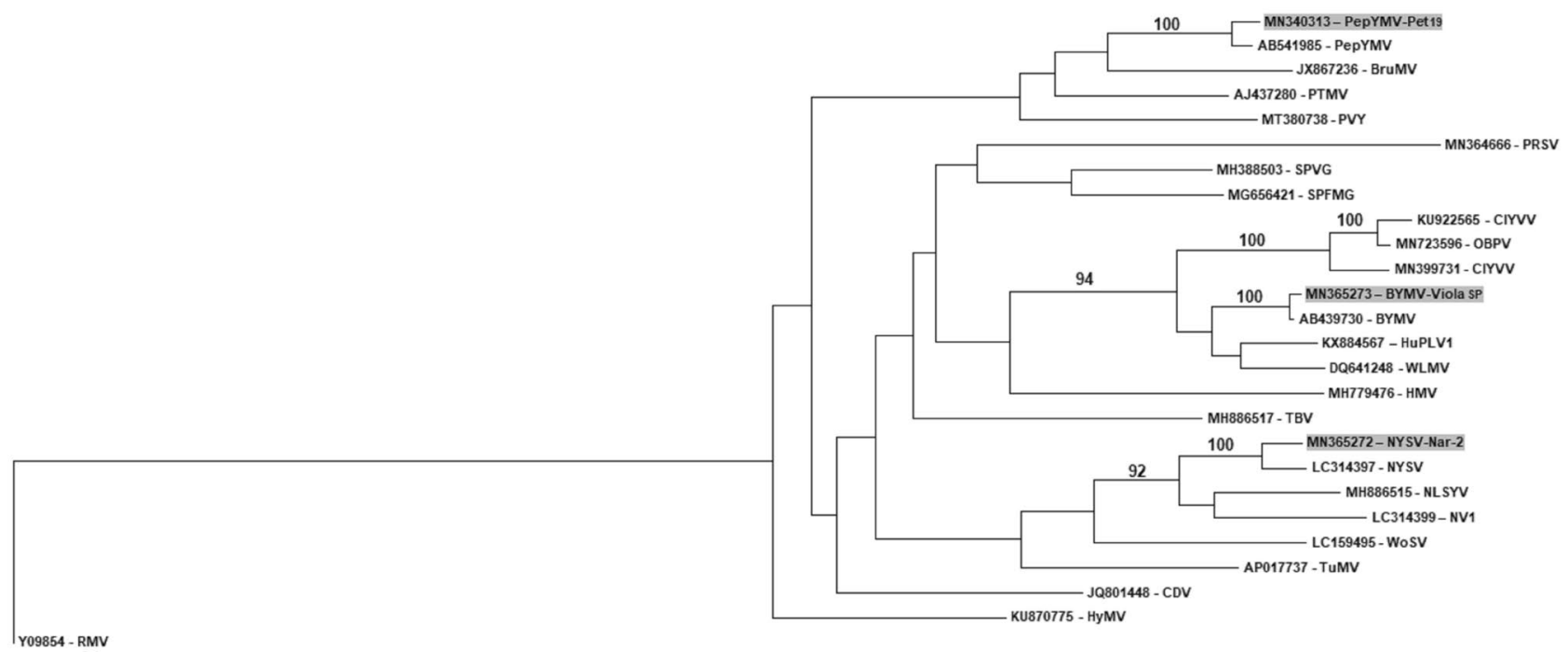

Fig. 3 Phylogenetic tree constructed by maximum likelihood using CI partial sequences available in GenBank for Potyvirus isolates from Petunia hybrida (PepYMV-Pet 19), Narcissus cyclamineus (NYSV-Nar-2) and Viola odorata (BYMV-Viola SP). The tree was constructed using the $\mathrm{HKY}+\mathrm{I}+\mathrm{G}$ nucleotide substitution model $(\mathrm{I}=0.2398, \mathrm{G}=1,0367)$ obtained by Modeltest v. 3.06 program. BruMV Brugmansia mosaic virus, $B Y M V$ bean yellow mosaic virus, $C D V$ Colombian datura virus, $C l Y V V$ Clover yellow vein virus, $H M V$ henbane mosaic virus, $H u P L V 1$ Hubei poty-like virus $1, H y M V$ Hyacinth mosaic virus, $N L S Y V$ Narcissus late season yellows virus, $N V 1$ Narcissus virus $1, N Y S V$ Narcissus yellow stripe virus, $O B P V$

faint stripe mosaic symptoms in narcissus plants have also been associated with the presence of potyviruses, the most prevalent being Narcissus degeneration virus, Narcissus late season yellows virus, NYSV, and Cyrtanthus elatus virus-A (Mowat et al. 1998; Raj et al. 2018). This is the first report of NYSV in narcissus plants in Brazil.

Petunia has been reported as the natural host of several viruses, including Potyvirus species, such as Petunia flower mottle virus (Feldhoff et al. 1998), potato virus Y (Baracsi et al. 2006) and turnip mosaic virus (Farzadfar et al. 2005). PepYMV was described in sweet pepper in Central and Southeast Brazil by Inoue-Nagata et al. (2002), and it has become the most important and widespread virus in pepper, occurring only in Brazil, where it was completely sequenced (Lucinda et al. 2012). Thus, this is the first report of natural infection of this virus in an ornamental species of the Solanaceae family.

Natural infection by cosmopolitan viruses, such as cucumber mosaic virus (CMV) and BYMV, has also been reported in $V$. odorata, in addition to Viola mottle virus described in Italy (Lisa and Dellavalle 1977), small rhabdovirus-like particles similar to orchid fleck virus (OFV) in Australia (Gowanlock and Dietzegen 1995), and Brevipalpus transmitted virus (BTV) in Brazil (Kitajima et al. 2010). In Brazil, the occurrence of BYMV in ornamental
Ocimum basilicum potyvirus, PepYMV pepper yellow mosaic virus, $P R S V$ papaya ringspot virus, $P T M V$ Peru tomato mosaic virus, $P V Y$ potato virus Y, $S P F M V$ sweet potato feathery mottle virus, $S P V G$ sweet potato virus $\mathrm{G}, T B V$ Tulip breaking virus, $T u M V$ turnip mosaic virus, $W L M V$ white lupin mosaic virus, WoSV wild onion symptomless virus. Homologous sequence from Ryegrass mosaiv virus (RMV-Genus Rymovirus) was used as outgroup. Bootstrap values obtained by the branch-and-bound method and computed after 1000 resamplings, followed by an MP reconstruction, are indicated near the branches

species has only been described in Gladiolus x hortulanus, Hippeastrum sp. and Lilium sp. (Kitajima 2020). BYMV is usually mechanically transmitted, as well as by more than 20 aphid species and by seed (to 3\%) (Brunt et al. 1996). However, BYMV-Viola SP was not transmitted to experimental hosts. This is the first report of BYMV in Viola odorata, in Brazil.

Narcissus and sweet violet are vegetatively propagated, which can make them vulnerable to the accumulation of viruses over subsequent generations. Thus, the international trade in plant propagules may expand the geographical range of viruses (Wylie et al. 2019). As such, the use of virus-free propagation material is essential for the sanitary status of seedlings.

Acknowledgements To Fundação de Amparo à Pesquisa do Estado de São Paulo (FAPESP 2017/18910-4).

Author contributions LMLD and MAVA planed, designed experimental work and wrote the manuscript. MAVA conducted biological and serological tests. AFR conducted RNA extractions and RT-PCR. RH conducted the sequencing of the potyvirus genomes. LMLD, MAVA and LKR conducted identification, molecular and phylogenetic analyzes. EWK collected $V$. odorata samples and conducted the transmission electron microscopy observations. 


\section{References}

Baracsi E, Kriston E, Palkovics L, Toth EK, Takacs A, Horvath J (2006) Petunia species as virus hosts and characterization of potato virus $\mathrm{Y}$ (PVY) strains isolated from petunias in Hungary. Acta Hortic 722:271-276. https://doi.org/10.17660/ActaHortic. 2006.722 .33

Brunt AA, Crabtree K, Dallwitz MJ, Gibbs AJ, Watson L, Zurcher EJ (eds) (1996) Plant viruses online: descriptions and lists from the VIDE database. Version: 20th August 1996. http://biology.anu. edu.au/Groups/MES/vide/. Accessed 11 Nov 2020

Farzadfar S, Ohshima K, Pourrahim R, Golnaraghi AR, Jalali S, Ahoonmanesh A (2005) Occurrence of Turnip mosaic virus on ornamental crops in Iran. Plant Pathol 54:261. https://doi.org/10. 1111/j.1365-3059.2004.01148.x

Feldhoff A, Wetzel T, Peters D, Kellner R, Krczal G (1998) Characterization of Petunia flower mottle virus (PetFMV), a new potyvirus infecting Petunia $x$ hybrida. Arch Virol 143:475-488. https://doi. org/10.1007/s007050050304

Granett AL, Provvidenti R (1975) Partial purification and serological relationship of three strains of Bean yellow mosaic virus. Ann Appl Biol 8:413-415. https://doi.org/10.1111/j.1744-7348.1975. tb01658.x

Gowanlock DH, Dietzegen RG (1995) Small rhabdovirus-like particles in violet (Viola spp.). Australas Plant Pathol 24:215-216. https:// doi.org/10.1071/APP9950215

Ha C, Coombs S, Revill PA, Harding RM, Vu M, Dale JL (2008) Design and application of two novel degenerate primer pairs for the detection and complete genomic characterization of potyviruses. Arch Virol 153:25-36. https://doi.org/10.1007/ s00705-007-1053-7

Inoue-Nagata AK, Fonseca MEN, Resende RO, Boiteux LS, Monte DC, Dusi NA, Ávila AC, van der Vlugt RAA (2002) Pepper yellow mosaic virus, a new potyvirus in sweetpepper, Capsicum annuиm. Arch Virol 147:849-855. https://doi.org/10.1007/ s007050200032

Kitajima EW (2020) An annotated list of plant viruses and viroids described in Brazil (1926-2018). Biota Neotrop 20(2):e20190932. https://doi.org/10.1590/1676-0611-BN-2019-0932
Kitajima EW, Rodrigues JCV, Freitas-Astua J (2010) An annotated list of ornamentals naturally found infected by Brevipalpus mitetransmitted viruses. Sci Agric 67:348-371. https://doi.org/10. 1590/S0103-90162010000300014

Lisa V, Dellavalle G (1977) Viola mottle virus, a new member of the Potexvirus group. J Phytopathol 89:82-89. https://doi.org/10. 1111/j.1439-0434.1977.tb02843.x

Lucinda N, Rocha WB, Inoue-Nagata AK, Nagata T (2012) Complete genome sequence of pepper yellow mosaic virus, a potyvirus, occurring in Brazil. Arch Virol 157:1397-1401. https://doi.org/ 10.1007/s00705-012-1313-z

Moura MF, Mituti T, Marubayashi JM, Gioria R, Kobori RF, Pavan MA, Silva N, Krause-Sakate R (2011) A classification of Pepper yellow mosaic virus isolates into pathotypes. Eur J Plant Pathol 131:549-552. https://doi.org/10.1007/s10658-011-9836-9

Mowat WP, Duncan GH, Dawson S (1998) An appraisal of the identities of potyviruses infecting narcissus. In: VII International Symposium on virus diseases of ornamental plants. https://doi.org/10. 17660/ActaHortic.1988.234.24

Paiva PDO, Reis MV, Sant'Ana GS, Bonifácio FL, Guimaraes PHS (2020) Flower and ornamental plant consumers profile and behavior. Ornam Hortic 26:333-345. https://doi.org/10.1590/2447536X.v26i3.2158

Portal do Governo (2019) Estado de SP tem destaque na produção de flores e plantas ornamentais. available in https://www.saopaulo.sp. gov.br/ultimas-noticias/estado-de-sp-tem-destaque-na-producaode-flores-e-plantas-ornamentais/. Accessed 01 Sept 2020

Raj R, Kaur C, Agrawal L, Chauhan PS, Kumar S, Raj SK (2018) Fulllength genome sequence of Cyrtanthus elatus virus-a isolated from Narcissus tazetta in India. 3 Biotech 8:168. https://doi.org/ 10.1007/s13205-018-1189-z

Revers F, Garcia JA (2015) Chapter three-molecular biology of potyviruses. Adv Virus Res 92:101-199. https://doi.org/10.1016/bs. aivir.2014.11.006

Wylie SJ, Tran TT, Nguyen DQ, KohSH CA, Xu W, Jones MGK, Li $\mathrm{H}$ (2019) A virome from ornamental flowers in an Australian rural town. Arch Virol 164:2255-2263. https://doi.org/10.1007/ s00705-019-04317-7 